\title{
PENERAPAN SANKSI PENENGGELAMAN KAPAL ASING PELAKU ILLEGAL FISHING OLEH PEMERINTAH INDONESIA (PERSPEKTIF HUKUM INTERNASIONAL)
}

\author{
Siti Munawaroh \\ Universitas Bhayangkara \\ Siti.munawaroh55@yahoo.com
}

\begin{abstract}
Indonesia is an archipelagic country which most of its territory consists of vast territorial waters (sea) and is geographically the largest archipelagic country in the world. The Indonesian Sea has an area of 5.8 million km2 consisting of; territorial sea with an area of 0.8 million $\mathrm{km} 2$, archipelago sea 2.3 million $\mathrm{km} 2$, and EEZ 2.7 million $\mathrm{km} 2$, and has 17,480 islands with a coastline of 95,181 km2, and has a very large and diverse fisheries potential. This research uses the normative study method of finding the rule of law, principles of law, and legal doctrine to answer legal issues in applying the sanctions of foreign vessels that do illegal fishing. The potential of fisheries is an economic potential that can be utilized for the future of the nation as a basis for national development. However, there are still irresponsible parties who take Indonesia's marine products illegally or commonly referred to as illegal fishing. Illegal fishing is a criminal act that can be subject to sanctions.
\end{abstract}

Keywords: Sanctions, Foreign ships, Illegal fishing.

\begin{abstract}
ABSTRAK
Indonesia merupakan negara kepulauan yang sebagian besar wilayahnya terdiri dari wilayah perairan (laut) yang sangat luas dan secara geografis merupakan negara kepulauan terbesar di dunia. Laut Indonesia memiliki luas sebesar 5,8 juta $\mathrm{km} 2$ yang terdiri dari; laut teritorial dengan luas 0,8 juta $\mathrm{km} 2$, laut nusantara 2,3 juta $\mathrm{km} 2$, dan ZEE 2,7 juta km2, serta memiliki pulau sebanyak 17.480 pulau dengan garis pantai $95.181 \mathrm{~km} 2$, serta memiliki potensi perikanan yang sangat besar dan beragam. Penelitian ini menggunakan metode peneltian normatif yakni untuk menemukan aturan hukum, prinsip-prinsip hukum, dan doktrin hukum untuk menjawab masalah hukum dalam penerapan sanksi kapal asing yang melakukan illegal fishing. Potensi perikanan yang dimiliki merupakan potensi ekonomi yang dapat dimanfaatkan untuk masa depan bangsa sebagai dasar pembangunan nasional. Namun, terhadap besarnya produksi laut Indonesia tersebut masih ada pihak-pihak yang tidak bertanggung jawab yang mengambil hasil laut Indonesia secara ilegal atau biasa disebut sebagai illegal fishing. Illegal fishing merupakan suatu tindakan kriminal yang bisa dikenakan sanksi hukuman.
\end{abstract}

Kata Kunci: Sanksi, Kapal Asing, illegal fishing. 


\section{PEDAHULUAN}

Laut merupakan ruang perairan di muka bumi yang menghubungkan daratan dengan daratan dan bentuk-bentuk alamiah lainnya. Kesatuan geografis dan ekologis beserta segenap unsur terkait, sebagai suatu sistem yang diatur oleh ketentuan perundang-undangan nasional maupun internasional yang bertujuan untuk menjadikannya gatra dinamis ekonomis yang memerlukan pengusahaan. Oleh karena itu, kekayaan laut tersebut berubah menjadi sumber daya alam, dan selanjutnya dari sumber daya alam yang diusahakan tersebut menjadi salah satu modal kesejahteraan dan kemakmuran rakyat serta untuk pembangunan bangsa dalam mewujudkan cita-cita nasional. ${ }^{1}$

Indonesia merupakan negara kepulauan yang sebagian besar wilayahnya terdiri dari wilayah perairan (laut) yang sangat luas dan secara geografis merupakan negara kepulauan terbesar di dunia. Laut Indonesia memiliki luas sebesar 5,8 juta $\mathrm{km} 2$ yang terdiri dari; laut teritorial dengan luas 0,8 juta $\mathrm{km} 2$, laut nusantara 2,3 juta km2, dan ZEE 2,7 juta km2, serta memiliki pulau sebanyak 17.480 pulau dengan garis pantai $95.181 \mathrm{~km} 2$, serta memiliki potensi perikanan yang sangat besar dan beragam. Potensi perikanan yang dimiliki merupakan potensi ekonomi yang dapat dimanfaatkan untuk masa depan bangsa sebagai dasar pembangunan nasional. Namun, terhadap besarnya produksi laut Indonesia tersebut masih ada pihak-pihak yang bertanggung jawab yang mengambil hasil laut Indonesia secara ilegal atau biasa disebut sebagai illegal fihing.

Maraknya kegiatan illegal fishing yang terjadi di laut Indonesia semakin mengkhawatirkan, berdasarkan data Badan Pangan Dunia atau FAO, mencatat kerugian Indonesia per tahun akhibat illegal fishing adalah sebesar Rp30 triliun. Jumlah tersebut dinilai cukup kecil oleh Menteri Kelautan dan Perikanan, Susi Pudjiastuti. Menurut Susi, kerugian negara akhibat illegal fishing per tahun sebenarnya bisa mencapai lebih dari 20 miliar dolar Amerika atau sekitar Rp300 trilyun sehingga selama sepuluh tahun terakhir, total kerugian negara mencapai Rp3.000 triliun. Kerugian tersebut salah satunya merupakan akhibat dari banyaknya kapal asing ilegal yang menangkap ikan di Indonesia, jumlah kapal

${ }^{1}$ Abdul Qodir Jaelani, “Politik Hukum Putusan Mahkamah Konstitusi Nomor 36/PUU- 
asing yang berizin sekitar lebih dari 1.000 unit dan yang tidak berizin berkisar 3-5 kali lipatnya. Jumlah tangkapan satu kapal mencapai 600-800 ton pertahun. ${ }^{2}$

Illegal fishing merupakan penangkapan ikan yang dilakukan secara illegal yang dilakukan oleh orang asing ataupun oleh warga negara Indonesia sendiri. Tindakan tersebut dilakukan dengan berbagai cara yang tidak sesuai dengan Undang-Undang No. 31 Tahun 2004 jo.UU No. 45 Tahun 2009 tentang Perikanan (UU Perikanan). Sebagaimana dinyatakan dalam Pasal 8 UU Perikanan yakni: “ setiap orang dilarang melakukan penangkapan ikan dan atau pembudidayaan ikan dengan menggunakan bahan kimia, bahan biologis, bahan peledak, alat dan atau cara, dan atau bangunan yang dapat merugikan dan atau membahayakan kelestarian sumber daya ikan dan atau lingkungannya di wilayah pengelolaan perikanan Republik Indonesia "Selain itu menurut Badan pangan dan Pertanian Dunia (FAO), tindak pidana di bidang perikanan atau illegal fishing disebut dengan istilah Illegal, Unregulated, and Unreported Fishing (IUU-Fishing), yang berarti bahwa penangkapan ikan dilakukan secara illegal, tidak dilaporkan dan tidak sesuai dengan aturan yang telah ditetapkan. ${ }^{3}$

Keberadaan Undang-Undang No. 45 Tahun 2009 tentang Perikanan merupakan langkah positif dan merupakan landasan atau aturan dalam memutuskan persoalan hukum yang terkait dengan illegal fishing. UndangUndang Perikanan mengadopsi beberapa ketentuan hukum internasional tentang kelautan yang salah satunya adalah Konvensi Perserikatan Bangsa-Bangsa tentang Hukum Laut (United Convention on the Law of the Sea/UNCLOS) 1982 dan Indonesia telah meratifikasi UNCLOS tersebut melalui UU No. 17 Tahun 1985.

UNCLOS 1982 menempatkan Indonesia memiliki hak berdaulat (sovereign rights) untuk melakukan pemanfaatan konservasi dan pengelolaan sumber daya ikan di Zona Ekonomi Eksklusif dan laut lepas yang dilaksanakan berdasarkan persyaratan atau standar internasional yang berlaku. Zona Eksklusif Ekonomi tersebut memunyai status hukum khusus yang bersifat sui generisdan sui

2 Susi: "Illegal Fishing" Rugikan Negara Rp300 Triliun Per Tahun", http://finance.detik.com/read/2014/12/01/152125/2764211/4/menteri-susi-kerugian-akhibat-illegalfishing-rp-240-triliun, diakses pada 20 Maret 2018

${ }^{3}$ FAO-IUU Fishing dalam Code of Conduct For Responsible Fisheries, 1995. 
juris $^{4}$ yang berarti dalam pandangan hukum wilayah ZEE dalam hal ini tidak dapat disamakan dengan perlakuan hukum di wilayah teritorial yang merupakan wilayah kedaulatan suatu negara. Hal tersebut juga ditegaskan dalam konsideran UU No. 32 Tahun 2014 tentang Kelautan yang menyebutkan bahwa pengelolaannya harus sesuai dengan kepentingan pembangunan nasional penduduk dari negara yang bersangkutan. Pengelolaan lautan harus merefleksikan kedaulatan bangsa yang harus dijaga keberlangsungan dan sustainabilitasnya, serta tidak boleh dieksploitasi sekadar untuk pemenuhan kebutuhan ekonomi yang dikuasai oleh pihak-pihak tertentu.

\section{METODOLOGI}

Penelitian ini menggunakan metode penelitian normatif yakni penelitian hukum yang dilakukan untuk menemukan solusi untuk masalah hukum dan masalah hukum yang ada. Hasil penelitian ini dimaksudkan untuk memberikan resep masalah yang diusulkan. Menurut Peter Mahmud Marzuki ${ }^{5}$, penelitian hukum adalah proses untuk menemukan aturan hukum, prinsip-prinsip hukum, dan doktrin hukum untuk menjawab masalah hukum dalam penerapan sanksi kapal asing yang melakukan illegal fishing.

\section{PEMBAHASAN}

\section{Pengaturan Illegal Fishing Menurut UNCLOS 1982}

United Nations Conventions on the Law of Sea 1982 secara garis besar membedakan wilayah laut dimana negara dapat menegakkan hukumnya terhadap IUU Fishing, yaitu wilayah laut yang berada di bawah kedaulatan dan wilayah laut dimana suatu negara memiliki yurisdiksi. Kawasan laut yang tunduk di bawah kedaulatan suatu negara pantai atau kepulauan adalah perairan pedalaman dan laut teritorial atau perairan kepulauan dan laut teritorial. Sedangkan kawasan laut dimana suatu negara pantai atau kepulauan memiliki hak berdaulat dan yurisdiksi adalah ZEE dan landas kontinen. Wilayah ZEE mempunyai status hukum yang sui generis (unik atau berbeda). ${ }^{6}$ Keunikan terletak pada eksistensi hak dan kewajiban

\footnotetext{
${ }^{4}$ Didik Mohammad Sodik, Hukum Laut Internasional dan Pengaturannya di Indonesia: Rafika Aditama, 2011, h. 103.

5 Peter Mahmud Marzuki, Penelitian Hukum, Kencana Pranada Media Group, Jakarta, 2010, h. 35.

${ }^{6}$ Istilah sui generis digunakan untuk menyebut jenis-jenis aturan hukum yang dibuat secara khusus untuk mengatur suatu hal yang bersifat spesifik atau unik.
} 
negara pantai negara pantai dan negara lain atas ZEE. Berbeda dengan di laut terotorial, dimana negara pantai mempunyai kedaulatan, di ZEE negara pantai hanya memilki hak berdaulat.Hak berdaulat tersebut terbatas pada eksplorasi dan eksploitasi sumber daya kelautan, baik sumber daya hayati maupun non-hayati. ${ }^{7}$

Di dalam UNCLOS 1982 disebutkan hak dan yurisdiksi negara pantai di ZEE meliputi eksplorasi dan eksploitasi sumber daya kelautan (hayati dan nonhayati, membuat dan memberlakukan peraturan perundang-undangan yang berkaitan dengan eksplorasi dan eksploitasi sumber daya kelautan, pembangunan pulau buatan dan instalasi permanen lainnya, dan mengadakan penelitian ilmiah kelautan. UNLOS 1982 tidak mengatur tentang IUU Fishing secara khusus. Namun, UNCLOS 1982 hanya mengatur secara umum tentang penegakkan hukum di laut teritorial maupun ZEE suatu negara. Jika pelanggaran terhadap peraturan perundang-undangan negara pantai terjadi di laut teritorial ataupun perairan pedalaman suatu negara, maka sesuai dengan kedaulatan yang diberikan oleh Pasal 2 UNCLOS 1982, negara pantai dapat memberlakukan aturan hukumnya terhadap kapal tersebut.

Ketentuan Pasal 2 tersebut di atas hanya akan berlaku apabila pelanggaran tersebut membawa dampak bagi negara pantai atau mengganggu keamanan negara pantai sebagaimana ditentukan dalam Pasal 27 ayat (1) UNCLOS 1982 yang mengatur bahwa "yurisdiksi kriminal negara pantai tidak dapat dilaksanakan di atas kapal asing yang sedang melintasi laut teritorial untuk menangkap siapapun atau untuk mengadakan penyidikan yang bertalian dengan kejahatan apapun yang dilakukan di atas kapal selama lintas demikian, kecuali dalam hal-hal berikut: (a) apabila akhibat kejahatan yang dirasakan di negara pantai; (b) apabila kejahatan itu termasuk jenis yang mengganggu kedamaian negara tersebut atau ketertiban laut wilayah; (c) apabila telah diminta bantuan penguasa setempat oleh nahkoda kapal dan wakil diplomatik atau pejabat konsuler negara bendera; atau (d) apabila tindakan demikian diperlukan untuk menumpas perdagangan gelap narkotika atau

\footnotetext{
${ }^{7}$ Usmawadi Umar; Seminar Nasional de ngan tema "Tiga Puluh Tahun Konvensi Hukum Laut PBB (UNCLOS) 1982 dan Tantangan Diplomasi Kelautan Indonesia”, Palembang, 13 November 2012 Kerja Sama Ditjen Hukum dan Perjanjian Internasional, Kemlu dengan Fakultas Hukum Universitas Sriwijaya, Palembang, p. 3-10., dalam Abdul Qodir Jaelani dan Udiyo Basuki, "Illegal, Unreported, and Unregulated (IUU) Fishing: Upaya Mencegah dan Memberantas Illegal Fishing dalam Membangun Poros Maritim Indonesia", Jurnal Supremasi Hukum, Vol. 3, Juni 2014.
} 
bahan psikotropik. ${ }^{8}$ Namun, apabila unsur-unsur yang disebutkan dalam Pasal 27 ayat (1) UNCLOS 1982 tidak terpenuhi, maka negara pantai tidak dapat menerapkan yurisdiksi pidananya terhadap kapal tersebut. Pasal 27 ayat (5) UNCLOS 1982 selanjutnya merujuk pada Bab V tentang ZEE dalam hal pelanggaran terhadap peraturan perundang-undangan negara yang berkaitan dengan eksplorasi dan eksploitasi sumber daya perikanan.

Penegakkan hukum terhadap Illegal Fishing yang terdapat dalam UNCLOS yakni diatur dalam Pasal 73 seperti Penegakkan Peraturan Perundangundangan negara pantai, yaitu:

Pertama, negara pantai dapat melaksanakan hak berdaulatnya untuk melakukan eksplorasi, eksploitasi, konservasi, dan pengelolaan sumber kekayaan hayati di ZEE, mengambil tindakan demikian, termasuk menaiki kapal, memeriksa, menangkap dan melakukan proses peradilan, sebagaimana diperlukan untuk menjamin ditaatinya peraturan perundang-undangan yang ditetapkannya sesuai dengan ketentuan konvensi ini. Kedua, kapal-kapal yang ditangkap dan awak kapalnya harus segera dibebaskan setelah diberikan suatu uang jaminan yang layak atau bentuk jaminan lainnya.Ketiga, hukuman negara pantai yang dijatuhkan terhadap pelanggaran peraturan perundang-undangan perikanan di ZEE tidak boleh mencakup pengurungan, jika tidak ada perjanjian sebaliknya antara negara-negara yang bersangkutan, atau setiap bentuk hukuman badan lainnya. Keempat, dalam hal penangkapan atau penahanan kapal asing, negara pantai harus segera memberitahukan kepada negara bendera melalui saluran tepat, mengenai tindakan yang diambil dan mengenai setiap hukuman yang kemudian dijatuhkan.

Sesuai dengan ketentuan Pasal 73 UNCLOS 1982 terkait dengan illegal fishing, jika kapal asing tidak mematuhi peraturan perundang-undangan negara pantai dalam hal konservasi sumber daya perikanan, negara pantai dapat melakukan penangkapan terhadap kapal tersebut. Akan tetapi, kapal dan awak kapal yang ditangkap tersebut harus segera dilepaskan dengan reasonable bond(uang jaminan yang layak) yang diberikan kepada negara pantai. Hukuman terhadap kapal asing tersebut juga tidak boleh dalam bentuk hukuman badan yaitu

\footnotetext{
${ }^{8}$ Pasal 2 UNCLOS 1982
} 
penjara, hal tersebut dikarenakan di ZEE, negara pantai hanya memunyai hak berdaulat (soverign right), bukan hak berdaulat.

Illegal fishing di dalam pengaturannya sering disandingkan dengan tindak pidana perikanan lainnya, yaitu Unreported and Unregulated Fishing yang secara harfiah dapat diartikan sebagai kegiatan perikanan yang tidak sah, kegiatan perikanan yang tidak diatur oleh peraturan yang ada, atau aktivitasnya tidak dilaporkan kepada suatu institusi atau lembaga pengelola perikanan yang tersedia. Dengan kata lain illegal fishing yaitu kegiatan penangkapan ikan yang masuk kategori sebagai berikut: ${ }^{9}$

1. Dilakukan oleh orang atau kapal asing pada suatu perairan yang menjadi yurisdiksi suatu negara tanpa izin dari negara tersebut atau bertentangan dengan peraturan perundang-undangan yang berlaku.

2. Bertentangan dengan peraturan nasional yang berlaku atau kewajiban internasional.

3. Dilakukan oleh kapal yang mengibarkan bendera suatu negara yang menjadi anggota organisasi pengelolaan perikanan regional tetapi beroperasi tidak sesuai dengan ketentuan pelestarian dan pengelolaan yang diterapkan oleh organisasi tersebut atau ketentuan hukum internasional yang berlaku.

Dalam hukum nasional terdapat beberapa aturan atau norma hukum yang mengatur tentang tindak pidana perikanan (illegal fishing) yaitu; UU No. 31 Tahun 2004 dan perubahannya UU No. 45 Tahun 2009 tentang Perikanan; UU No. 27 Tahun 2007 tentang Pengelolaan Wilayah Pesisir dan Pulau-Pulau Kecil serta aturan pelaksanaan lainnya seperti: PP No. 54 Tahun 2005 tentang Usaha Perikanan; PP No. 60 Tahun 2007 tentang Konservasi Sumber Daya Ikan, PP no. 30 Tahun 2008 tentang Penyelenggaraan Penelitian dan Pengembangan Perikanan, Peraturan Menteri Kelautan dan Perikanan No. PER.13/MEN/2005 tentang Forum Koordinasi Penanganan Tindak Pidana di Bidang Perikanan; Peraturan Menteri Kelautan dan Perikanan No.PER.14/MEN/2005 tentang Komisi Nasional Pengkajian Sumbe Daya Ikan, Peraturan Menteri Kelautan dan Perikanan No.PER.15/MEN/2005 tentang Penangkapan Ikan dan atau Pembudidaya Ikan di Wilayah Pengelolaan Perikanan Republik Indonesia yang Bukan Untuk Tujuan Komersial; Peraturan Menteri Kelautan dan Perikanan No.PER.05/MEN/2008 tentang Usaha Perikanan Tangkap; Peraturan Menteri Kelautan dan Perikanan

\footnotetext{
${ }^{9}$ Victor P.H. Nikijuluw, Dimensi Sosial Ekonomi Perikanan Illegal Blue Water Crime, PT. Pustaka Cidesindo, Jakarta, 2008), h. 18.
} 
No.PER.06/MEN/2008 tentang Penggunaan Pukat Hela di Perairan Kalimantan Timur Bagian Utara; Peraturan Menteri Kelautan dan Perikanan No.PER.08/MEN/2008 tentang Penggunaan Alat Penangkap Ikan Jaring Langsung (Gill Net) di ZEEI.

\section{Implementasi Ketentuan UNCLOS 1982 Terkait dengan Tindak Pidana Illgal} Fishing.

Indonesia telah meratifikasi UNCLOS 1982 dengan Undang-Undang No 17 Tahun 1985 tentang Pengesahan United Nations Convention on the Law of the Sea. Oleh karena itu, bagi negara kepulauan dan negara pantai seperti Indonesia, peristiwa tersebut merupakan langkah yang patut dibanggakan. Berlakunya yurisdiksi UNCLOS 1982 tersebut berarti status kepulauan Indonesia dengan yurisdiksi terhadap eksploitasi kekayaan alam hayati dan non-hayati, sudah tidak diragukan lagi secara internasional.

Implementasi ketentuan UNCLOS 1982 terkait dengan tindak pidana di bidang perikanan (illegal fishing), berdasarkan teori transformasi dan teori delegasi, ketentuan-ketentuan yang ada dalam Konvensi Hukum Laut 1982 tersebut ditransformasikan dan didelegasikan ke dalam hukum nasional melalui perundang-undangan. Implementasi dari ketentuan UNCLOS, salah satunya terkait dengan ketentuan mengenai pembagian wilayah laut sebagaimana telah diuraikan sebelumnya. Penjabaran ketentuan UNCLOS dalam hukum nasional terkait dengan pengaturan mengenai wilayah laut Indonesia, diatur lebih lanjut dalam Undang-Undang No. 6 Tahun 1996 tentang Perairan Indonesia.

Menurut Undang-Undang No. 6 Tahun 1996 tentang perairan Indonesia , wilayah perairan Indonesia meliputi laut teritorial Indonesia, perairan kepulauan, dan perairan pedalaman. Wilayah perairan tersebut menjadi wilayah yang menjadi wilayah yang menjadi di bawah Kedaulatan Negara Kesatuan Republik Indonesia.Oleh karena itu, Indonesia memunyai wewenang penuh terhadap wilayah tersebut dan dapat menetapkan hukum dalam wilayah kedaulatannya. ${ }^{10}$ Hal tersebut ditegaskan kembali dalam Undang-Undang No. 32 Tahun 2014 tentang Kelautan (UU Kelautan). Undang-Undang Kelautan juga menegaskan pembagian wilayah laut, sebagaimana UU Perairan telah membagi

${ }^{10}$ Budiyono, Monograf, Pembatasan Kedaulatan Negara Kepulauan Atas Wilayah Laut, , Justice Publisher, Bandar Lampung, 2014, h. 84. 
wilayah laut Indonesia. Menurut Pasal 7 UU Kelautan, kedaulatan Indonesia sbagai negara kepulauan meliputi wilayah daratan, perairan pedalaman, perairan kepulauan, dan laut teritorial, termasuk ruang udara di atasnya serta dasar laut, dan tanah dibawahnya, termasuk kekayaan alam yang terkandung di dalamnya. Kedaulatan Indonesia tunduk pada ketentuan peraturan perundang-undangan dan UNCLOS 1982.

Terkait dengan praktik illegal fishing di wilayah perairan, keterlibatan pihak asing dalam pencurian ikan dapat digolongkan menjadi dua, yaitu: ${ }^{11}$ Pertama, pencurian semi legal, yaitu pencurian ikan yang dilakukan oleh kapal asing dengan memanfaatkan surat izin penangkapan legal yang dimiliki oleh pengusaha lokal, dengan menggunakan kapal berbendera lokal atau bendera negara lain. Praktik ini tetap dikategorikan sebagai illegal fishing karena selain menangkap ikan di wilayah perairan yang bukan haknya, pelaku illegal fishing langsung mengirim hasil tangkapan tanpa melalui proses pendaratan ikan di wilayah yang sah. Praktik ini sering disebut sebagai praktik "pinjam bendera" atau Flag of Convenience (FOC).

Kedua, pencurian murni illegal yaitu proses penangkapan ikan yang dilakukan oleh nelayan asing dan kapal asing yang menggunakan benderanya sendiri untuk menangkap ikan di wilayah suatu negara. Namun, illegal fishing tidak hanya dilakukan oleh pihak asing tetapi juga oleh para nelayan atau pengusaha lokal. Illegal fishing yang dilakukan oleh para nelayan atau pengusaha lokal dapat digolongkan menjadi tiga golongan yakni;

1. Kapal ikan berbendera Indonesia bekas kapal ikan asing yang dokumennya palsu atau bahkan tidak memiliki isin;

2. Kapal ikan Indonesia (KII) dengan dokumen "aspal" atau pejabat yang mengeluarkan dokumen tersebut, bukan pejabat yang berwenang, atau dokumen palsu;

3. Kapal ikan Indonesia (KII) yang tanpa dilengkapi dokumen sama sekali, artinya menangkap ikan tanpa izin.

11 Suhardi, Aspek Hukum Penanganan Tindak Pidana Perikanan (illegal Fishing) di Indonesia, dalam http//mukhtar-api.blogspot.co.id, diakses pada 22 Maret 2018. 
Terkait dengan praktik illegal fishing tersebut, berdasarkan hasil FGD pejabat Pengawasan Sumber Daya Kelautan dan Perikanan KKP, ${ }^{12}$ modus operandi dari IUU Fishing yang terjadi di wilayah pengelolaan perairan Republik Indonesia tersebut adalah

1. tanpa izin;

2. Memiliki izin tapi melanggar ketentuan, misalnya ketentuan mengenai alat tangkap, fishing ground, dan port of call;

3. Pemalsuan dokumen;

4. Manipulasi persyaratan (Deletion Certificate, Bill od sale);

5. Trans-shipment di laut tidak pernah lapor di pelabuhan perikanan;

6. Bendera ganda (double flagging).

Implementasi UNCLOS terkait dengan illegal fishing juga diatur dalam UU No. 5 tahun 1983 tentang ZEEI.Undang-undang ini memuat ketentuan yang mengatur kegiatan pemanfaatan sumber daya ikan di ZEE. Pada Pasal (4) undangundang tersebut dijelaskan bahwa dalam wilayah ZEEI, Indonesia memunyai hak berdaulat, hak-hak lain, yurisdiksi dan kewajiban-kewajiban atas sumber daya yang ada di ZEEI. ${ }^{13}$ Dalam rangka melaksanakan hak berdaulat, hak-hak lain, yurisdiksi dan kewajiban, aparatur penegak hukum Republik Indonesia yang berwenang, dapat mengambil tindakan-tindakan penegak hukum sesuai dengan UU No. 8 tahun 1981 tentang Hukum Acara Pidana. Hal tersebut juga ditegaskan dalam UU No. 45 Tahun 2009 tentang Perubahan atas UU No. 31 Tahun 2004 Tentang Perikanan, Pasal 27 ayat (2) dan ayat (3) yang mengatur setiap orang yang memiliki dan atau mengoperasikan kapal penangkap ikan berbendera asing digunakan untuk melakukan penangkapan ikan di ZEEI wajib memiliki SIPI, serta Setiap orang yang mengoperasikan kapal penangkap ikan berbendera Indonesia di wilayah pengelolaan perikanan Negara Republik Indonesia atau mengoperasikan kapal penangkap ikan berbendera asing di ZEEI wajib membawa SIPI asli.

Selanjutnya berdasarkan Pasal 29 UU Perikanan, usaha perikanan di Wilayah Pengelolaan Perikanan Republik Indonesia hanya boleh dilakukan oleh warga negara Republik Indonesia atau badan hukum Indonesia. Pengeculaib

\footnotetext{
${ }^{12}$ Hasil FGD dengan Dirjen Pengawasan Sumber Daya Kelautan dan Perikanan KKP, 23 Februari 2015.

${ }^{13}$ Pasal 4 UU No.5 tahun 1983 tentang ZEEI.
} 
terhadap ketentuan sebagaimana dimaksud pada ayat (1) diberikan kepada orang atau badan hukum asing yang melakukan usaha penangkapan ikan di ZEEI, sepanjang hal tersebut menyangkut kewajiban Negara Republik Indonesia berdasarkan persetujuan internasional atau ketentuan hukum internasional yang berlaku.

Undang-Undang Perikanan ini mengatur bahwa setiap orang yang melakukan dan pemasaran ikan di Wilayah Pengelolaan Perikanan Republik Indonesia (WPPRI) dan di ZEEI wajib memiliki Surat Izin Usaha Perikanan (SIUP), Surat Izin Penangkapan Ikan (SIPI), dan Surat Izin Kapal Pengangkut Ikan (SIKPI). Pada kenyataannya kapal-kapal asing banyak yang tidak memenuhi syarat tersebut, dalam hal ini tidak memiliki kelengkapan surat-surat tersebut. Bahkan, ada juga yang memiliki surat-surat yang ternyata merupakan surat palsu. ${ }^{14}$ Oleh karena itu, UU Perikanan mengatur tentang larangan pemalsuan surat dengan penggunaan SIUP, SIPI, dan SIKPI palsu. Setiap kapal perikanan yang melakukan kegiatan perikanan wajib memiliki Surat Persetujuan Berlayar yang dikeluarkan oleh syahbandar di pelabuhan perikanan dan surat laik operasi kapal perikanan dari pengawas perikanan dikeluarkan oleh pengawas perikanan setelah dipenuhi persyaratan administrasi dan kelayakan teknis. ${ }^{15}$

Apabila terjadi pelanggaran terhadap ketentuan-ketenuan tersebut, untuk menegakkan hukum Indonesia, berdasarkan undang-undang ini juga dibentuk pengadilan perikanan yang berwenang memeriksa, mengadili, dan memutus tindak pidana bidang perikanan yang terjadi di WPPRI, baik yang dilakukan oleh warga negara Indonesia maupun warga negara asing. Para pelaku illegal fishing tersebut akan diperiksa dan diadili di pengadilan lalu dijatuhi putusan apabila bersalah. Para pelaku yang bersalah, menurut undang-undang ini akandijatuhi hukuman berupa sanki administratif, pidana penjara, ataupun membayar denda.Selain sanksi-sanksi tersebut, UU No. 45 Tahun 2009 tentang Perikanan mengatur dengan tegas pemberian sanksi berupa pembakaran dan atau penenggelaman kapal asing yang melakukan illegal fishing di wilayah perairan Republik Indonesia. Hal ini tercantum dalam pasal 69 ayat (4), bahwa dalam

\footnotetext{
${ }^{14}$ Hasil wawancara yang dilakukan oleh Novianti dengan Direktorat Kepolisian Perairan Polda Kepulauan Riau, Maret 2015.

${ }^{15}$ Pasal 42 dan Pasal 43 Undang-Undang Nomor 31 Tahun 2004 Tentang Perikanan.
} 
melaksanakan fungsi sebagai penyidik dan atau pengawas perikanan, penyidik dan atau pengawas perikanan dapat melakukan tindakan khusus berupa pembakaran dan atau penenggelaman kapal perikanan yang berbendera asing berdasarkan bukti permulaan yang cukup.

Kebijakan pemerintah dalam menenggelamkan kapal menimbulkan pro dan kontra dalam masyarakat serta kekhawatiran bahwa tindakan penenggelaman tersebut akan berdampak pada hubungan antarnegara, khususnya dari negaranegara asal nelayan tersebut. Bahkan, tindakan tersebut dikaitkan dengan pelanggaran HAM, pelanggaran hukum, dan tindakan yang tidak manusiawi. Namun, berdasarkan FGD dengan pakar hukum kelautan dari UNPAD, ${ }^{16}$ kebijakan peneggelaman kapal yang melanggar aturan di perairan Indonesia tidak akan memberburuk hubungan antarnegara. Terdapat beberapa alasan mengapa penenggelaman kapal tidak memperburuk hubungan antarnegara, yakni sebagai berikut:

a. Tidak ada negara di dunia ini yang membenarkan tindakan warganya yang melakukan kejahatan di negara lain.

b. Kapal nelayan asing yang ditenggelamkan adalah kapal yang tidak memiliki izin operasi untuk melakukan penangkapan ikan di wilayah laut Indonesia. Mereka melakukan kejahatan di wilayah Indonesia.

c. Tindakan penenggelaman dilakukan di wilayah kedaulatan dan merupakan hak berdaulat Indonesia di ZEEI.

d. Tindakan penenggelaman dilakukan atas dasar payung hukum yang sah, yaitu Pasal 69 ayat (4) UU Perikanan No. 45 Tahun 2009 tentang Perikanan. Sebelum tahun 2009, memang proses penenggelaman harus melalui putusan pengadilan yang berkekuatan hukum tetap.

Terkait dengan tindakan penenggelaman kapal, UU Perikanan telah mengatur tindakan tersebut.Bahkan dalam konvensi internasional juga tidak terdapat ketentuan khusus yang melarang tindakan penenggelaman kapal. Namun, yang perlu diperhatikan adalah proses penenggelaman kapal, khususnya yang diatur dalam Pasal 69 ayat (4) dan Pasal 76A UU Perikanan. Pasal 69 menentukan bahwa penyidik dan atau pengawas perikanan dapat melakukan tindakan khusus

${ }^{16}$ Hasil FGD yang dilakukan oleh Novianti dengan Pakar Hukum Kelautan dari UNPAD, 23 Februari 2013. 
berupa pembakaran dan atau penenggelaman kapal ikan berbendera asing yang hanya didasarkan pada bukti permulaan. Selanjutnya dalam Pasal 76A UU Perikanan diatur bahwa terhadap pemusnahan kapal dapat dilakukan setelah mendapatkan persetujuan dari Ketua Pengadilan Negeri.Namun, ketentuan tersebut tidak menyebutkan tolok ukur terkait persetujuan yang diberikan oleh Ketua Pengadilan terkait apakah kapal tersebut dapat dihancurkan?Ataukan dilakukan penahanan untuk selanjutnya dilelang atau bahkan dihibahkan kepada penduduk terdekat setempat di wilayah domisili terjadinya tindak pidana perikanan tersebut? Hal ini akan menimbulkan keraguan seorang hakim dalam menentukan persetujuannya atas tindakan pemusnahan kapal. Untuk itu dibutuhkan paying hukum yang memberikan landasan tolok ukur bagi seorang Ketua Pengadilan Negeri dalam memberikan persetujuan pemusnahan kapal.Dalam hal ini, azas kepastian dapat menjadi pegangan sehingga Hakim memiliki keyakinan dalam memberikan persetujuan.

Terkait dengan sanksi tindak pidana perikanan sebagaimana diatur dalam UU Perikanan secara umum dapat menimbulkan efek jera. Namun, terhadap pelaku tindak pidana, terutama warga negara asing yang melakukan tindak pidana perikanan di wilayah ZEEI belum menimbulkan efek jera karena tidak dapat dijatuhi pidana penjara kecuali telah ada perjanjian antara Pemerintah Republik Indonesia dengan pemerintah negara yang bersangkutan (Pasal 102 UU No. 31 Tahun 2004). Ketentuan ini paralel dengan Pasal 73 ayat (2) UNCLOS 1982 yang tidak membenarkan juga peraturan negara pantai untuk melaksanakan hukuman penjara atau hukuman badan jika tidak ada perjanjian dengan negara yang bersangkutan.

Terkait dengan sanksi administratif bagi pelaku pelanggaran sebagaimana diatur dalam UU No. 45 tahun 2009 Perbuahan UU No. 31 tahun 2004 tentang Perikanan belum menimbulkan efek jera dan tidak efektif. Sebagai contoh terhadap kapal ikan asing yang melakukan penangkapan di ZEEI dengan menggunakan ABK tidak sesuai dengan ketentuan sebagaimana diatur dalam Pasal 35 A ayat (3) UU No. 45 Tahun 2009 yakni saknsi administratif berupa peringatan, pembekuan izin, atau pencabutan izin, tidak efektif dikarenakan kapal ikan asing yang melakukan penangkapan ikan di wilayah pengelolaan perikanan 
Indonesia tidak dilengkapi dokumen dan tidak ada agen di Indonesia. Selain itu menurut pejabat Lantamal Tanjung Pinang, ${ }^{17}$ yang menjadi kendala penyidik dalam menjalankan tugas penyidikan tindak pidana di bidang perikanan yakni penyidikan terhadap nahkoda yang berkebangsaan asing yang melakukan penangkapan ikan di ZEEI. Dalam hal ini undang-undang telah mengatur bahwa terhadap nahkoda tidak dapat dilakukan penahanan, dan penyidik tidak memilki tempat untuk menempatkan tersangka yang tidak ditahan sehingga akan menyulitkan dalam melakukan pengawasan. Sementara kendala lainnya, terhadap nahkoda kapal berkewarganegaraan asing maupun saksi yang dalam proses peridangan, imigrasi selaku lembaga yang mengurus orang asing yang akan dipulangkan ke negaranya, tidak mau menerima pentitipan nahkoda maupun saksi tersebut, sebelum proses perkaranya berkekuatan hukum tetap. Sesuai dengan ketentuan UNCLOS dan peraturan perundang-undangan, apabila terjadi penangkapan maka nahkoda dan ABK tidak diperkenankan untuk diturunkan dari kapal bersangkutan.Mereka hanya dapat dilakukan penahanan di luar yang dalam hal ini hanya di kapal milik yang bersangkutan.Terkait dengan hal tersebut, terdapat hak hidup dari nahkoda dan ABK yang terhalang karena yang bersangkutan tidak dapat turun dari kapal dan atau tidak dapat melakukan perawatan kapal.Hal ini pada gilirannya menjadi tanggung jawab penyidik maupun penyelidik untuk menghidupi nahkoda dan ABK maupun merawat kapal yang ditahan.Hal ini seringkali menjadi kendala bagi para aparatur penegak hukum dalam penanganan tindak pidana perikanan (illegal fishing). Kendala utama yang dihadapi adalah para penegak hukum tidak memiliki anggaran khusus untuk melakukan perawatan ataupun menghidupi nahkoda dan para ABK. Di sisi lain, apabila hal ini tidak dipenuhi, maka penegak hukum terancam atas tindakan pelanggaran HAM, yaitu hak hidup dari nahkoda dan ABK-nya.

Implementasi UNCLOS 1982 juga diatur dalam sektor pelayaran di perairan Indonesia yaitu melalui UU No. 17 Tahun 2018 tentang Pelayaran.Pelayaran adalah satu kesatuan sistem yang terdiri atas angkutan perairan, ke pelabuhan, keselamatan dan keamanan, serta perlindungan

\footnotetext{
${ }^{17}$ Hasil wawancara Novianti dengan pejabat Lantamal, op.cit.
} 
lingkungan maritim. ${ }^{18}$ Ruang lingkup berlakunya UU Pelayaran berlaku juga bagi kapal asing yang berlayar di perairan Indonesia.Kapal asing dilarang mengangkut penumpang dan atau barang antarpulau atau antarpelabuhan di wilayah perairan Indonesia.Hal yang berhubungan dengan kapal ikan dituangkan pada Bab IX tentang Kelaikan Kapal.Kapal penangkap ikan sebelum melakukan operasi juga harus memenuhi persyaratan keselamatan kapal yang diberi sertifikat keselamatan oleh Menteri. ${ }^{19}$

\section{KESIMPULAN}

Implementasi ketentuan UNCLOS 1982 yang terkait dengan penangkapan ikan ilegal diimplementasikan atau diterjemahkan ke dalam beberapa undangundang nasional, yaitu UU No. 6 tahun 1996 tentang Perairan Indonesia, UU No. 32 tahun 2014 tentang Kelautan, UU No. 5 tahun 1983 tentang EEZ, UU No. 45 tahun 2009 tentang Perubahan atas UU No. 31 tahun 2004 tentang Perikanan yang secara tegas mengatur sanksi dalam bentuk membakar dan atau menenggelamkan kapal asing yang melakukan penangkapan ikan ilegal di perairan teritorial Republik Indonesia. Implementasi UNCLOS 1982 juga diatur dalam sektor pelayaran di perairan Indonesia, yaitu melalui UU No. 17 tahun 2008 tentang Pengiriman. Pengiriman adalah sistem terpadu yang terdiri dari transportasi air, pelabuhan, keselamatan dan keamanan, dan perlindungan lingkungan laut.

Aspek hukum dari tindakan tegas tenggelamnya kapal asing tidak bertentangan dengan hukum internasional, terutama dalam UNCLOS 1982 karena subyek yang dilindungi dalam Pasal 73 ayat (3) UNCLOS 1982 adalah manusia, bukan kapal, di mana orang dapat didenda atau dideportasi tanpa dipenjara sementara kapal dapat disita atau bahkan ditenggelamkan oleh Pemerintah Indonesia.

\footnotetext{
${ }^{18}$ Pasal 1 angka (1) UU No. 17 Tahun 2008 tentang Pelayaran.

${ }^{19}$ Pasal 126 UU No. 17 Tahun 2008.
} 


\section{DAFTAR BACAAN}

\section{BUKU}

Budiyono, Monograf, Pembatasan Kedaulatan Negara Kepulauan Atas Wilayah Laut, Justice Publisher, Bandar Lampung, 2014.

Didik Mohammad Sodik, Hukum Laut Internasional dan Pengaturannya di Indonesia: Rafika Aditama, 2011.

Peter Mahmud Marzuki, Penelitian Hukum, Kencana Pranada Media Group, Jakarta, 2010, h. 35.

Victor P.H. Nikijuluw, Dimensi Sosial Ekonomi Perikanan Illegal Blue Water Crime, Pustaka Cidesindo, Jakarta, 2008.

\section{JURNAL}

Abdul Qodir Jaelani dan Udiyo Basuki, "Illegal, Unreported, and Unregulated (IUU) Fishing: Upaya Mencegah dan Memberantas Illegal Fishing dalam Membangun Poros Maritim Indonesia”, Jurnal Supremasi Hukum, Vol. 3, Juni 2014.

Qodir Jaelani, "Politik Hukum Putusan Mahkamah Konstitusi Nomor 36/PUU$\mathrm{X} / 2012$ Tentang Pembubaran BP MIGAS: Upaya Mengembalikan Kedaulatan Negara Menuju Perlindungan HAM", Jurnal Panggung Hukum, Vol. 1 No. 1 Tahun 2015.

Usmawadi Umar; Seminar Nasional dengan tema "Tiga Puluh Tahun Konvensi Hukum Laut PBB (UNCLOS) 1982 dan Tantangan Diplomasi Kelautan Indonesia", Palembang, 13 November 2012 Kerja Sama Ditjen Hukum dan Perjanjian Internasional, Kemlu dengan Fakultas Hukum Universitas Sriwijaya, Palembang, 2002.

\section{WEBSITE}

Suhardi, Aspek Hukum Penanganan Tindak Pidana Perikanan (illegal Fishing) di Indonesia, dalam http//mukhtar-api.blogspot.co.id, diakses pada 22 Maret 2018.

Susi: "Illegal Fishing" Rugikan Negara Rp300 Triliun Per Tahun", http://finance.detik.com/read/2014/12/01/152125/2764211/4/menteri-susikerugian-akhibat-illegal-fishing-rp-240-triliun, diakses pada 20 Maret 2018.

\section{REGULASI DAN PERUNDANG-UNDANGAN}

Konvensi PBB tentang Hukum Laut 1982.

FAO-IUU Fishing (Kode Etik Perikanan Bertanggung Jawab, 1995).

UU No. 31 tahun 2004 dan amandemen UU No. 45 tahun 2009 tentang Perikanan. 
UU No. 27 tahun 2007 tentang Pengelolaan Wilayah Pesisir dan Pulau-Pulau Kecil dan peraturan pelaksanaan lainnya.

Peraturan Pemerintah No. 60 tahun 2007 tentang Konservasi Sumberdaya Ikan.

Peraturan Pemerintah No. 30 tahun 2008 tentang Implementasi Perikanan, Penelitian dan Pengembangan.

Peraturan Menteri Kelautan dan Perikanan No. PER.13 / MEN / 2005 tentang Forum Koordinasi Manajemen Perikanan di Bidang Perikanan.

Peraturan Menteri Kelautan dan Perikanan No. PER.14 / MEN / 2005 tentang Komisi Nasional untuk Penilaian Sumber Daya Ikan.

Peraturan Menteri Kelautan dan Perikanan No. PER.15 / MEN / 2005 tentang Penangkapan Ikan dan atau Pembudidaya Ikan di Wilayah Pengelolaan Perikanan Republik Indonesia Bukan Untuk Tujuan Komersial.

Peraturan Menteri Kelautan dan Perikanan No. PER. 05 / MEN / 2008 tentang Bisnis Perikanan Tangkap.

Peraturan Menteri Kelautan dan Perikanan No.PER.06 / MEN / 2008 tentang Penggunaan Hela Trawler di Perairan Kalimantan Utara; Peraturan Menteri Kelautan dan Perikanan No.PER.08 / MEN / 2008 tentang Penggunaan Ikan Penangkapan Langsung (Gill Net) di ZEEI. 